\title{
Article \\ The Corrosion and Wear Behaviors of a Medium-Carbon Bainitic Steel Treated by Boro-Austempering Process
}

\author{
Man Liu ${ }^{1}$, Wei Wang ${ }^{2, *}$, Haijiang $\mathrm{Hu}^{1}{ }^{1}$, Feng Cai ${ }^{1}$, Sheng Liu ${ }^{1}$ and Guang $\mathrm{Xu}{ }^{1}, * \mathbb{C}$ \\ 1 The State Key Laboratory of Refractories and Metallurgy, The Collaborative Innovation Center for Advanced \\ Steels of Ministry of Education, The Key Laboratory for Ferrous Metallurgy and Resources Utilization of \\ Ministry of Education, Wuhan University of Science and Technology, Wuhan 430081, China; \\ 13971287356@163.com (M.L.); huhaijiang@wust.edu.cn (H.H.); 15162249029@163.com (F.C.); \\ liusheng@wust.edu.cn (S.L.) \\ 2 Central Research Institute of BaoShan Iron \& Steel Co., Ltd., Shanghai 201900, China \\ * Correspondence: weiwang@baosteel.com (W.W.); xuguang@wust.edu.cn (G.X.); \\ Tel.: +86-027-6886-2813 (G.X.)
}

Citation: Liu, M.; Wang, W.; Hu, H.; Cai, F.; Liu, S.; Xu, G. The Corrosion and Wear Behaviors of a

Medium-Carbon Bainitic Steel Treated by Boro-Austempering Process. Metals 2021, 11, 1959. https://doi.org/10.3390/ met11121959

Academic Editor: Hannu Hänninen

Received: 10 November 2021 Accepted: 29 November 2021 Published: 6 December 2021

Publisher's Note: MDPI stays neutral with regard to jurisdictional claims in published maps and institutional affiliations.

Copyright: (c) 2021 by the authors. Licensee MDPI, Basel, Switzerland. This article is an open access article distributed under the terms and conditions of the Creative Commons Attribution (CC BY) license (https:// creativecommons.org/licenses/by/ $4.0 /)$.

\begin{abstract}
The effects of boro-austempering treatment on growth kinetics of borided layers, microstructure, and properties in a medium-carbon bainitic steel were investigated. The microstructure, distribution in coatings, corrosion, and wear properties of boro-austempered steels were characterized by a microscope, field-emission electron probe micro analyzer, scanning vibrating electrode technique system and wear resistance machine. The results show that the corrosion resistance of steels in different corrosive mediums was significantly enhanced by boro-austempering treatment. In addition, the wear performance of borided layers was improved by more than two times compared to bainitic substrates, proving a better wear property of samples treated through the boro-austempering route. The solubility of carbon and silicon in borides is very little. In addition, the dual-phase coating of $\mathrm{FeB}$ and $\mathrm{Fe}_{2} \mathrm{~B}$ was observed, and the internal stress induced during the growth of $\mathrm{Fe}_{2} \mathrm{~B}$ and $\mathrm{FeB}$ was almost eliminated. The preferential crystallographic growth directions of $\mathrm{Fe}_{2} \mathrm{~B}$ and $\mathrm{FeB}$ are [001] and [010], respectively, which belongs to the (100) plane. Finally, the kinetics equation $\mathrm{d}^{2}=0.125 \cdot \mathrm{t}$ of the borided layers at $1223 \mathrm{~K}$ was established.
\end{abstract}

Keywords: boro-austempering; bainitic transformation; boriding; corrosion resistance; wear property

\section{Introduction}

Bainitic steels are widely used as structural materials of bridges, engineering machinery, industrial equipment, oil, and gas pipelines, etc. High strength bainitic steels with adequate corrosion resistance and wear property are largely in demand. Many efforts have been made to meet the requirements by composition design and optimization of processing routes [1-4]. For example, Wang et al. [5] successfully fabricated a novel 35MnSiCrNiAlMo bainitic steel with yield strength, tensile strength, and elongation of $1400 \mathrm{MPa}, 1530 \mathrm{MPa}$ and $14 \%$, respectively, by slowly cooling from the temperature slightly higher than martensite start temperature $\left(\mathrm{M}_{\mathrm{s}}\right)$ to the temperature that was $20{ }^{\circ} \mathrm{C}$ lower than $\mathrm{M}_{\mathrm{s}}$. A small amount of Ni was added in high carbon bainitic steels to achieve excellent properties with a $2000 \mathrm{MPa}$ grade ultrahigh strength [6]. However, it took $30 \mathrm{~h}$ to finish the bainitic reaction. The ultimate tensile strength of $\sim 1755 \mathrm{MPa}$ and elongation of $\sim 18.1 \%$ in a medium-carbon bainitic steel was obtained through ausforming with a strain of 0.2 at $573 \mathrm{~K}$ [7]. Moreover, multi-step austempering treatments for bainitic transformation were proposed to refine bainite laths and improve properties [8,9].

Summarizing the existing literatures, it can be seen that the excellent properties of bainitic steels are achieved mainly through the following three methods. The first method is adding alloying elements to refine the microstructure and thus enhance the properties $[10,11]$. The second method is to use the complicated multi-step processing route 
or long austempering time $[12,13]$. The third method is to utilize deformation processing $[14,15]$. However, there are few studies attempting to enhance the surface properties of bainitic steels [16-18], which provides another effective way to tailor the properties and expand the application range of high-strength bainitic steels. Fabijanic et al. [16] produced the nitrocarburised layer on high-carbon bainitic steels by nitrocarburising treatment after finishing the bainitic reaction. The fatigue properties and hardness were improved by shot peening on bainitic steels [17]. It should be pointed out that bainite transformation and surface modification process are performed separately in works of literature $[16,17]$. Oliveira et al. [18] claimed that the boro-austempering treatment (the integrated boriding and austempering process) was a promising alternative to increase the wear resistance of advanced high-strength bainitic steels. previous study [19] indicated that the borided layers and bainite transformation in the center matrix were not significantly affected by each other during the boro-austempering treatment. From a commercial viewpoint, boro-austempering treatment has some advantages.

Since the boro-austempering treatment is successfully applied in cast irons [20,21], it has attracted much attention. However, very limited studies have been performed to fabricate high-strength bainitic steels by boro-austempering $[18,19]$. Though the hardness, compound phase and corrosion resistance in $0.5 \% \mathrm{NaCl}$ of boro-austempered steels were investigated in the author's previous study [19], several related key issues remain unsolved. For example, the corrosion resistance of boro-austempered steels in different corrosive mediums and the surface wear resistance have not been fully clarified. The kinetics of the as-prepared borided layers needs to be further investigated. The alloying element distributions from the coating to the substrate are also not clear. Therefore, the effects of boro-austempering treatment on microstructure, corrosion, and wear behaviors of mediumcarbon steel were investigated in the present study. The results provide the theoretical guidance for producing bainitic steels with higher surface corrosion resistance and excellent wear property by boro-austempering.

\section{Materials and Methods}

The chemical composition of the investigated steel is Fe-0.4C-2.0Si-2.8Mn-0.5Al (wt.\%), which was refined in a $50 \mathrm{~kg}$ vacuum induction furnace and then cast into an ingot. Afterwards, the ingot was hot-rolled to a $12 \mathrm{~mm}$ plate. Figure 1 displays the schematic of experimental procedures. Rectangle samples with dimensions of $50 \times 30 \times 20 \mathrm{~mm}^{3}$ were immersed in a salt bath at $1223 \mathrm{~K}$ for austenization and boriding, as indicated in Figure 1a. The salt bath was composed of $\sim 95 \mathrm{Na}_{2} \mathrm{~B}_{4} \mathrm{O}_{7}$ and $\sim 5 \%$ aluminum as the reducing agent for generating active boron atoms. The isothermal holding time at $1223 \mathrm{~K}$ was designed to be $0.5,1,2,6$, and $8 \mathrm{~h}$. After that, samples were immediately put into another salt bath $(50 \%$ $\mathrm{KNO}_{3}+50 \% \mathrm{NaNO}_{2}$ ) of $623 \mathrm{~K}$ for bainitic precipitation, followed by oil-cooling to the ambient temperature. To compare the difference of microstructure and properties between boro-austempered samples and merely austempered samples, another set of samples were selected and subjected to a similar heat process (without boriding, Figure 1b). Samples subjected to different treatments are represented by symbols in Table 1 .

Before microstructural characterization and performance examination, all samples were ultrasonically cleaned in water and organic solvent. A Zeiss optical microscope (OM, Oberkochen, Germany), VHX-5000 ultra-depth three-dimensional microscope (KEYENCE, Osaka, Japan), and Nova 400 Nano field-emission scanning electron microscope (SEM, FEI Company, Hillsboro, OR, USA) equipped with an electron backscatter diffraction (EBSD) technique were utilized for microstructural characterization. The alloying element distributions were detected by an EPMA-8050G electron probe micro analyzer (SHIMADZU, Kyoto, Japan). The corrosion resistance of produced layers and substrate in different corrosive mediums were evaluated via potentiodynamic polarization measurement (PPM) and an in situ scanning vibrating electrode technique (SVET) system. The potentiometric polarization curves were measured by a Zahner-Zennium electrochemical workstation (Zennium, Germany) with an electrochemical cell composed of three electrodes: a tested 
sample acting as a working electrode, a saturated $\mathrm{Hg} / \mathrm{HgCl}$ electrode working as the reference electrode, and a platinum foil serving as the counter electrode. For boro-austempering samples (Figure 1a) and the comparable sample (Figure 1b), the exposed areas were the as-prepared layer and the main bainite constituent, respectively. The open-circuit potentials of the boro-austempered sample and comparable sample in the same corrosive medium were almost equal, i.e., $-0.77 \mathrm{~V}(\mathrm{SCE}),-0.21 \mathrm{~V}(\mathrm{SCE})$, and $-0.41 \mathrm{~V}(\mathrm{SCE})$ in alkaline, acidic, and neutral environments, respectively. The specimen preparation and detailed measuring method of the SVET system were stated in the references [22,23]. The friction coefficient was assessed by a BMT-I multifunctional surface performance comprehensive tester (Jingcheng Testing Technology Co., Ltd., Jinan, China). A SiC ball with a diameter of $5 \mathrm{~mm}$ was selected with the following parameters: A load of $50 \mathrm{~N}$, sliding speed of 50 times per minute, and reciprocating slip length of $5 \mathrm{~mm}$. The wear performance was evaluated by an ML-100 wear resistance machine (Jingcheng Testing Technology Co., Ltd., Jinan, China). The sliding speed was designed as $0.2 \mathrm{~m} / \mathrm{s}$, and the applied load was $88 \mathrm{~N}$. The remaining weight of the samples were measured every $20 \mathrm{~min}$, and the total sliding time was $80 \mathrm{~min}$. The adhesion strength between the fabricated layer and bainitic substrate of steels was determined according to the VDI 3198 standard, and the hardness was measured by an HV-1000A Vickers hardness tester.

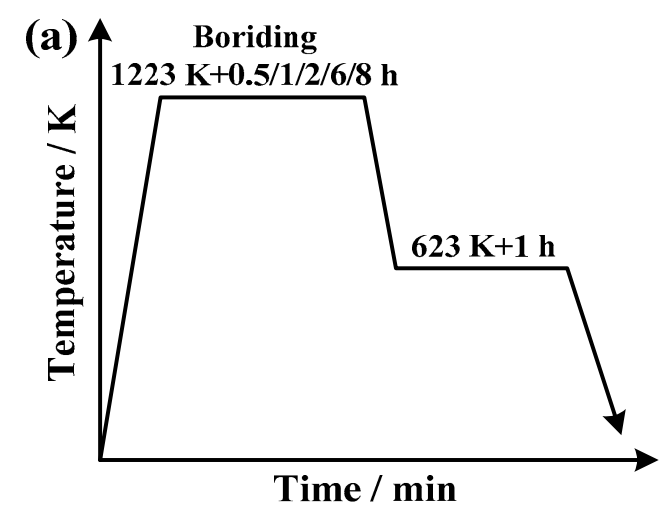

Figure 1. Schematic experimental procedures: (a) boro-austempering treatment; (b) merely austempering.

Table 1. The represented symbols of samples with different treatments.

\begin{tabular}{ccccccc}
\hline Treatments & $\mathbf{1 2 2 3} \mathbf{K}+\mathbf{2} \mathbf{h}$ & $\begin{array}{c}\text { Boriding } \\
\mathbf{1 2 2 3} \mathbf{K}+\mathbf{0 . 5} \mathbf{h}\end{array}$ & $\begin{array}{c}\text { Boriding } \\
\mathbf{1 2 2 3} \mathbf{K}+\mathbf{1} \mathbf{h}\end{array}$ & $\begin{array}{c}\text { Boriding } \\
\mathbf{1 2 2 3} \mathbf{K}+\mathbf{2} \mathbf{h}\end{array}$ & $\begin{array}{c}\text { Boriding } \\
\mathbf{1 2 2 3} \mathbf{K}+\mathbf{6} \mathbf{h}\end{array}$ & $\begin{array}{c}\text { Boriding } \\
\mathbf{1 2 2 3} \mathbf{K}+\mathbf{8} \mathbf{h}\end{array}$ \\
\hline Samples & NA-2 & BA- 0.5 & BA-1 & BA-2 & BA-6 & BA-8 \\
\hline
\end{tabular}

\section{Results and Discussion}

\subsection{Microstructure Characterization and Kinetics Analysis}

Figure 2 exhibits the microstructure of substrates in samples BA-2 and NA-2. The microstructures of both samples are analogous, consisting of mostly lath bainite (LB) and martensite/austenite islands (M/A).

To clarify the influence of boriding time on prior austenite grain size (PAGS), the prior austenite grains and boundaries of samples BA-1, BA-2, BA- 6 and BA-8 are exhibited in Figure 3. The PAGS were calculated based on the diagonal method used in the literature [24]. The average value of two diagonals, drawn randomly in each grain, is calculated as grain size, as shown in Figure 3a. The average PAGS can be obtained by multiple measurements, as listed in Table 2. It can be seen from Table 2 that the austenite grains grow up at a very slow speed as the boriding time increases at $1223 \mathrm{~K}$. Hence, boriding time at $1223 \mathrm{~K}$ has no significant influence on PAGS. 

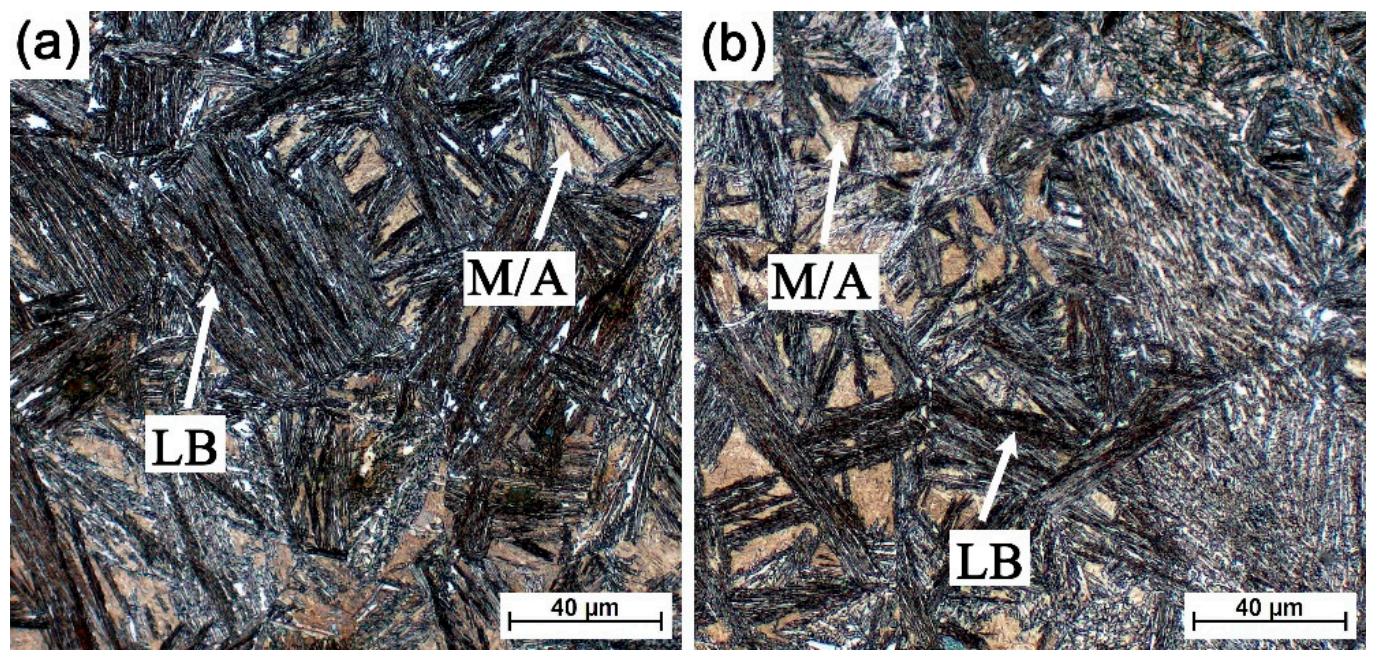

Figure 2. OM microstructure of substrates in samples (a) BA-2 and (b) NA-2.
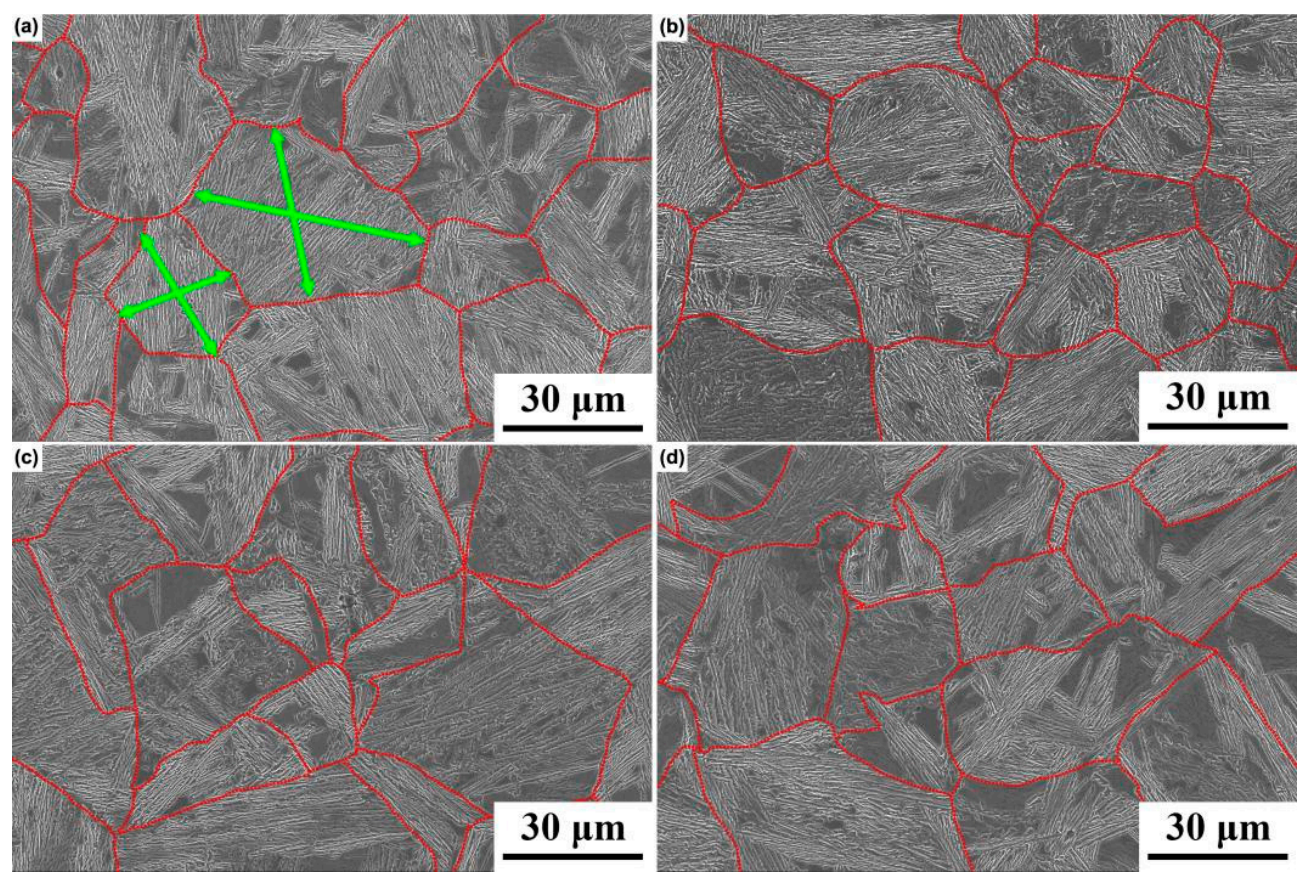

Figure 3. SEM images to measure the prior austenite grains of boro-austempered samples with varied boriding time: (a) $1 \mathrm{~h}$; (b) $2 \mathrm{~h}$; (c) $6 \mathrm{~h}$; (d) $8 \mathrm{~h}$.

Table 2. Average PAGS and coating thickness of different boro-austempered samples.

\begin{tabular}{cccccc}
\hline Samples & BA-0.5 & BA-1 & BA-2 & BA-6 & BA-8 \\
\hline Average PAGS $(\mu \mathrm{m})$ & $/$ & $31.1 \pm 8.4$ & $30.4 \pm 7.8$ & $34.0 \pm 8.9$ & $34.0 \pm 9.2$ \\
Coating thickness $(\mu \mathrm{m})$ & $3.4 \pm 0.8$ & $6.9 \pm 1.1$ & $28.6 \pm 1.4$ & $48.4 \pm 2.1$ & $62.9 \pm 3.7$ \\
\hline
\end{tabular}

Figure 4 presents the cross-sectional morphology of produced layers in boro-austempered samples. The produced layers after etching with $4 \%$ nital can be easily distinguished from substrate microstructure. It is observed that the produced layers are smooth and homogeneous with comb-like or needle-like morphologies. The depth of the compound layer of samples treated by different boriding times was measured by plotting random lines at the borided layers. The average values are given in Table 2 . It can be seen that 
the thickness of the compound layers increases from 3.4 to $62.9 \mu \mathrm{m}$ with the increase of boriding time.
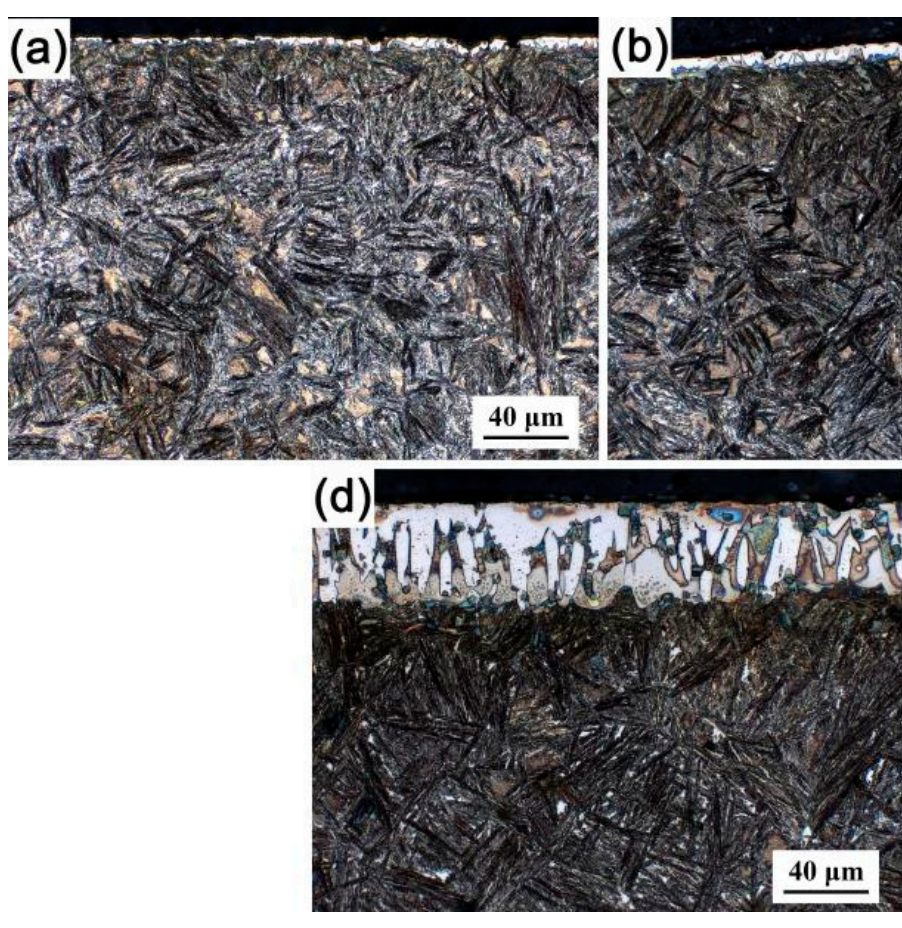
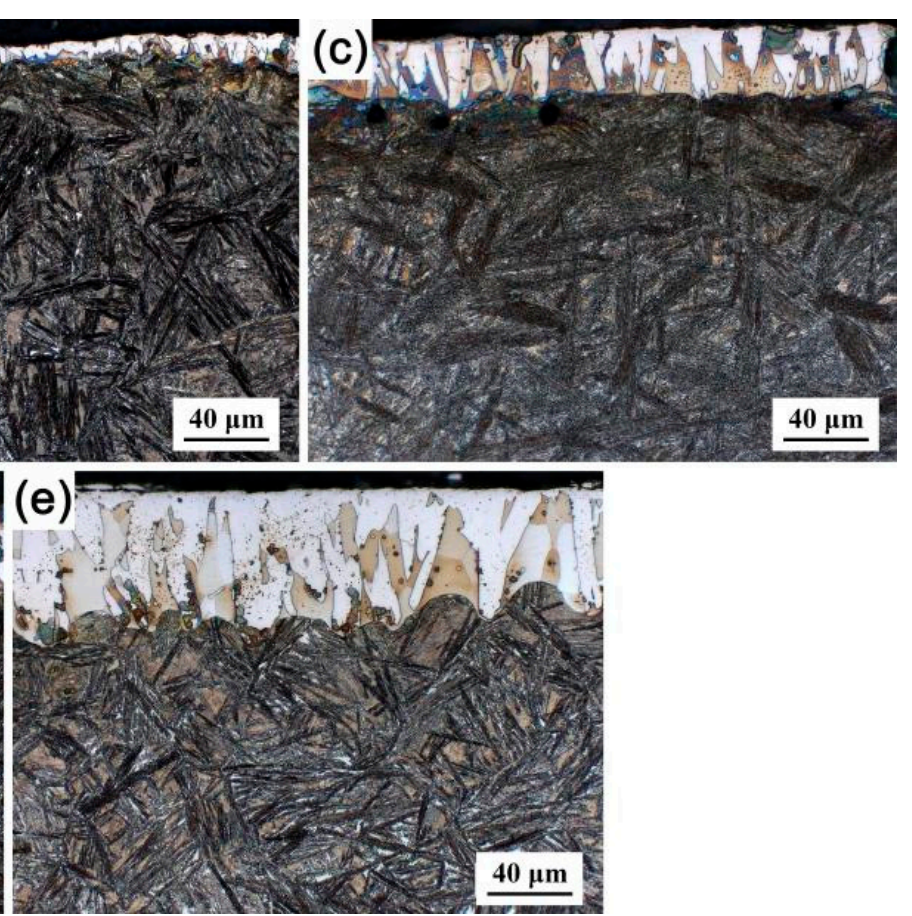

Figure 4. Cross-sectional OM morphologies of boro-austempered samples with different boriding times: (a) $0.5 \mathrm{~h}$; (b) $1 \mathrm{~h}$; (c) $2 \mathrm{~h} ;(\mathbf{d}) 6 \mathrm{~h} ;(\mathbf{e}) 8 \mathrm{~h}$.

According to the classical kinetic theory [25], the squared thickness of an as-produced layer as a function of the treated time at a given temperature can be described as Equation (1), and the fitting curve is given in Figure 5.

$$
\mathrm{d}^{2}=\mathrm{K} \cdot \mathrm{t}
$$

where $\mathrm{K}$ is a constant, representing the growth rate of produced coating at a given temperature. It is shown that the growth rate of the produced coating (the slope of the curve) is $0.125 \mu \mathrm{m}^{2} / \mathrm{s}$.

Due to the limited thickness of the produced layers at short borided durations, sample BA-8 was used to characterize the crystallographic growth direction of borides and the distributions of alloying elements from surface to substrate. Figure 6 displays the EBSD images of the borided coating of sample BA-8. The dual-phase coating of $\mathrm{FeB}$ and $\mathrm{Fe}_{2} \mathrm{~B}$ was obtained and a bcc structure formed between adjacent columnar $\mathrm{Fe}_{2} \mathrm{~B}$ grains, as displayed in Figure 6c. In addition, the disorientation at positions (1) and (2) indicates that the boundaries between the bcc structure and $\mathrm{Fe}_{2} \mathrm{~B}$ grains as well as $\mathrm{Fe}_{2} \mathrm{~B}$ and $\mathrm{FeB}$ grains are low-angle boundaries, which is beneficial to the strength. The misorientation at position (3) reveals the typical high-angle boundary of adjacent $\mathrm{Fe}_{2} \mathrm{~B}$ grains, which may be related to the intrinsic "toughness" of $\mathrm{Fe}_{2} \mathrm{~B}$. Moreover, it is known that internal stress is introduced by the formation of $\mathrm{Fe}_{2} \mathrm{~B}$ and $\mathrm{FeB}$ [26]. The kernel average misorientation (KAM) map (Figure 6a) shows that the internal stress induced during the growth of $\mathrm{Fe}_{2} \mathrm{~B}$ and $\mathrm{FeB}$ is almost eliminated. It is reported that the FeB first formed at the surface during boriding, and then the $\mathrm{Fe}_{2} \mathrm{~B}$ formed as matched to the crystallographic growth direction of FeB [26]. As confirmed by the inverse pole figures (IPF) in Figure $6 b, d, e$, the preferential crystallographic growth directions of $\mathrm{Fe}_{2} \mathrm{~B}$ and $\mathrm{FeB}$ are [001] and [010], respectively, which belongs to the (100) plane. 


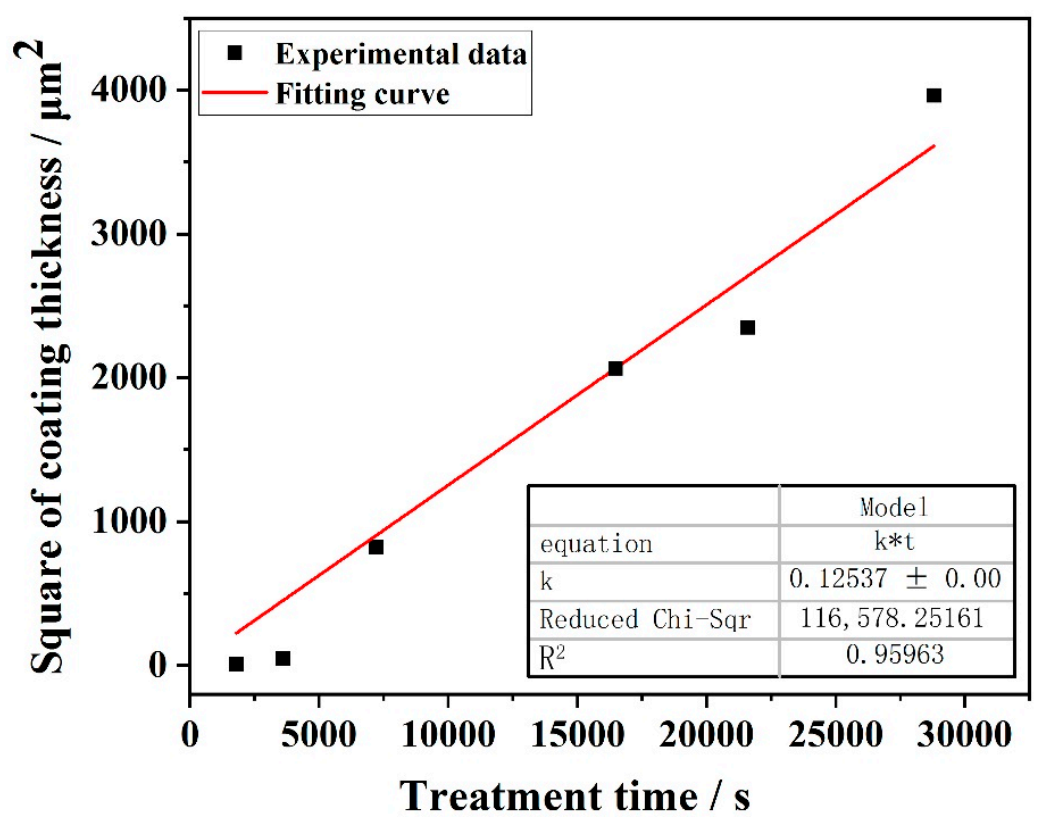

Figure 5. Square of the coating thickness versus boriding time and fitting curve.
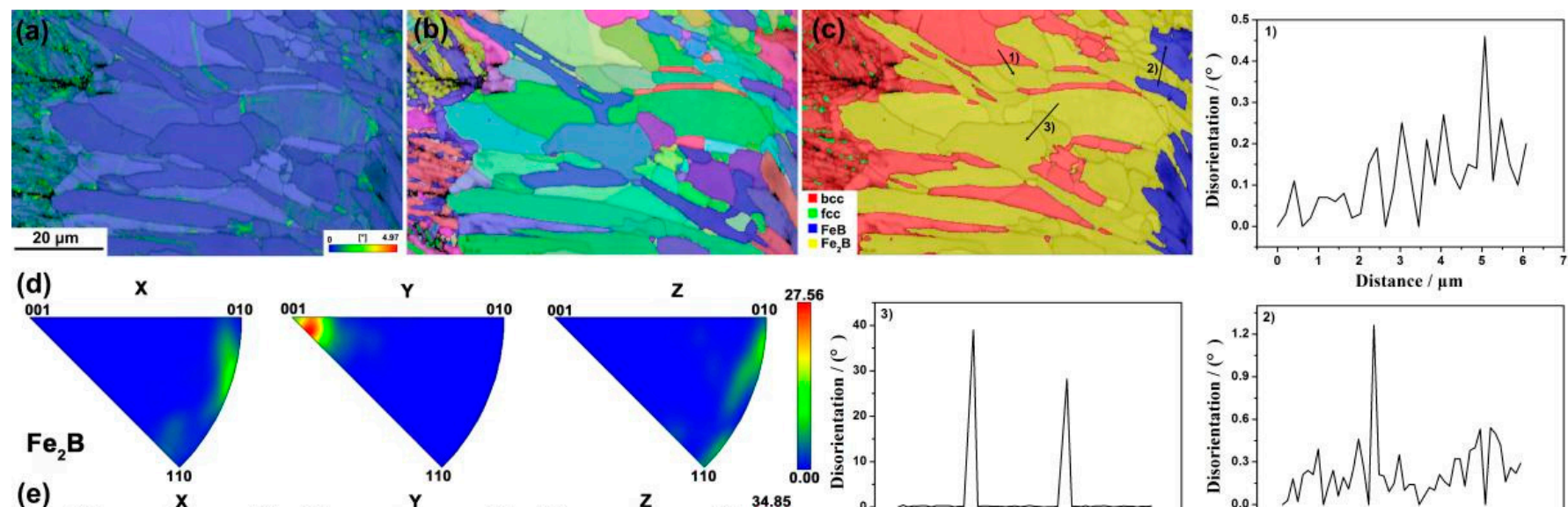

(e)
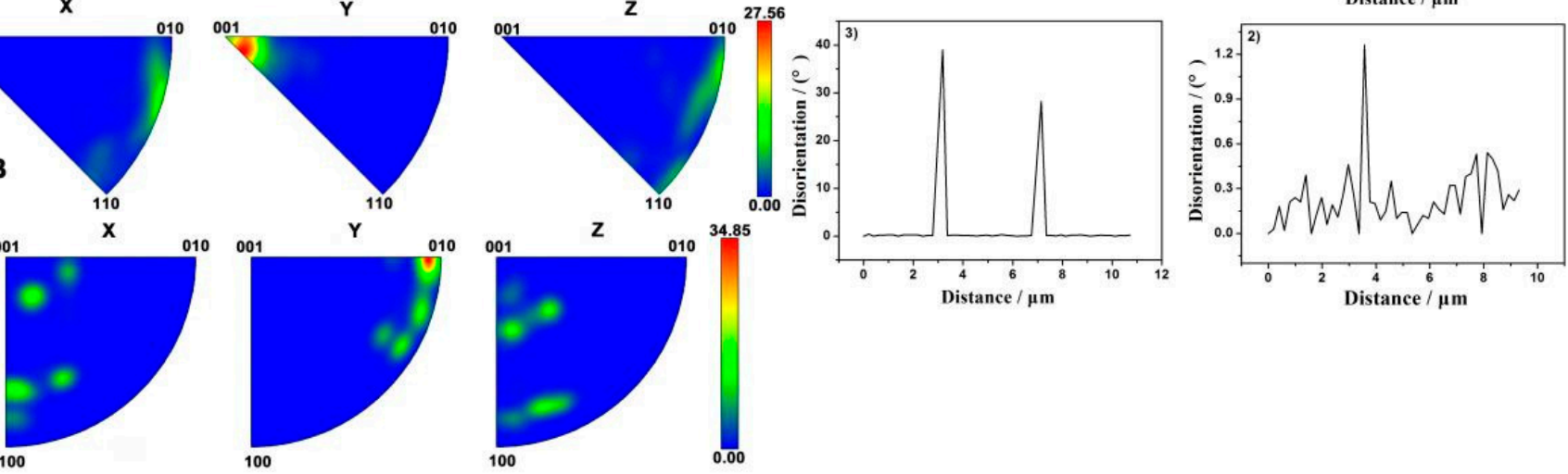

Figure 6. EBSD images of borided coating of sample BA-8: (a) KAM map; (b) IPF map; (c) phase map; (d) IPF of Fe 2 ; (e) IPF of FeB.

The map scanning along the depth of the produced layer from the surface of sample BA-8 is revealed in Figure 7, conducted on an EPMA-8050G electron probe micro analyzer. It is observed that there is a large amount of boron (B) content in the coating and fewer carbon (C) atoms, and the boride contains no silicon ( $\mathrm{Si}$ ) content. Si hinders the growth of borided layers, and $\mathrm{C}$ impedes the diffusion of B atoms. Carbon atoms prefer to gather at the interface between the layers and substrate, as reported in the author's previous study [19]. Moreover, Figure 7c shows that the boron concentration near the surface is higher than in other regions. It is known that FeB contains a higher boron content than $\mathrm{Fe}_{2} \mathrm{~B}$ [26]. Hence, the coating near the surface is supposed to be $\mathrm{FeB}$, and the coating near the substrate is $\mathrm{Fe}_{2} \mathrm{~B}$. 

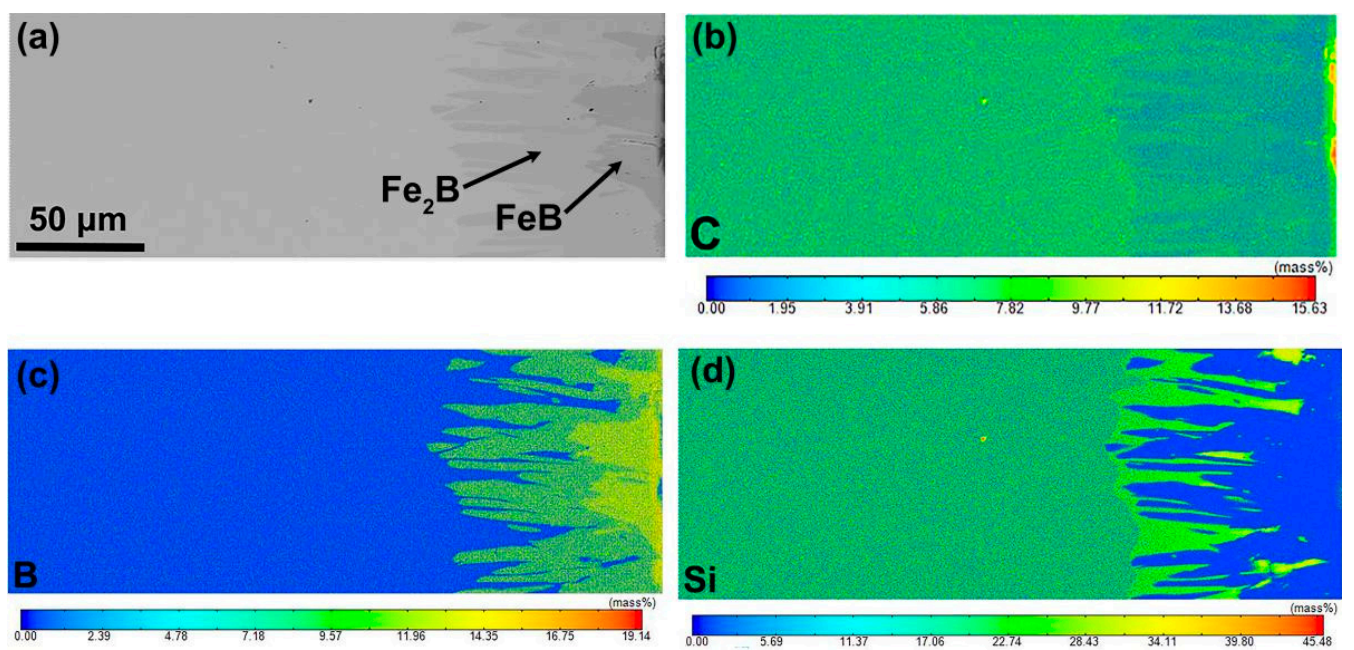

Figure 7. Map scanning of elements along the depth of the produced layer from the surface of sample BA-8: (a) origin image; (b) distribution of C content; (c) distribution of B content; (d) distribution of Si content.

\subsection{Evaluation of Adhesion Strength and Hardness Profiles}

The indentation method was utilized to characterize the adhesion strength and surface brittleness of as-prepared layers on the bainitic steel. The indentation test was conducted on the Rockwell-C hardness machine (Laizhou Hengyi Testing Instrument Co., Ltd. Yantai, China), and the indentation morphology of sample BA- 8 was observed by OM, as presented in Figure 8a. According to the level of cracking and coating delamination, the indentation rating is classified from HF1 to HF6 in the VDI-3198 standard [27], as presented in Figure 8b. Only indentations classified as HF1 and HF2 correspond to superior adhesion [28,29]. Based on the standard, the indentation rating of the as-prepared layer was evaluated to be HF2, indicating the superior adhesion strength of the produced layer with the bainite matrix. It is known that the disadvantage of mere boriding is the large brittleness and ease of flaking off with deformation, especially with a longer boriding duration [28]. Hence, tempering processes are normally conducted to reduce the brittleness and raise the adhesive strength between the borided layer and the matrix. In the boroaustempering process, the subsequent isothermal holding at $623 \mathrm{~K}$ for one hour for bainitic precipitation acts equivalent to the tempering process of borided layers. Consequently, the brittleness of borided layers evidently decreased, and the adhesion strength of the produced layer on bainitic steels increased. This is one of the advantages of boro-austempering processing routes.
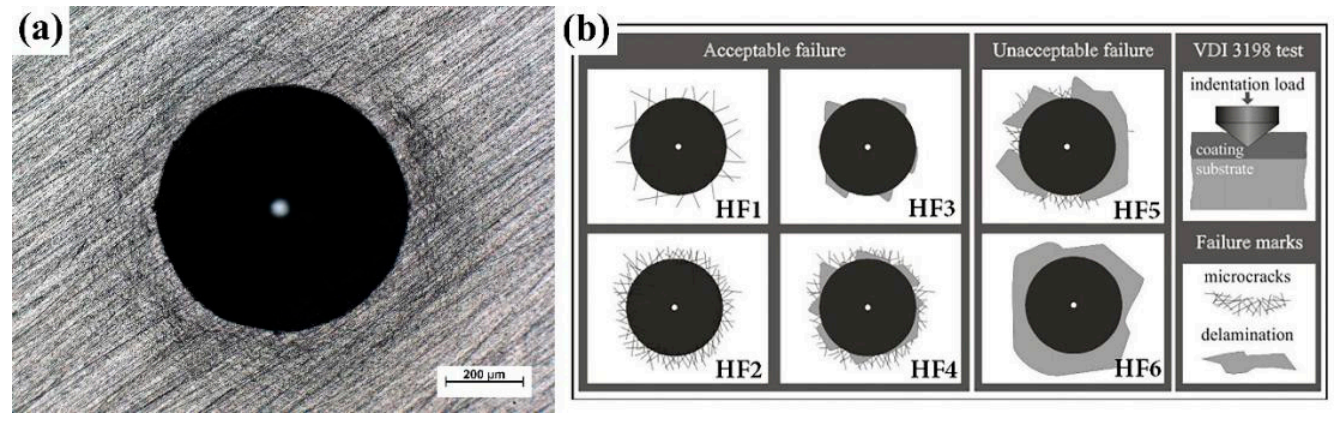

Figure 8. (a) OM indentation morphology of produced layer on bainitic steel; (b) the VDI-3198 standard of indentation ratings.

Figure 9 reveals the hardness profiles from the outermost produced layer to the substrate. Due to the limited thickness of produced layers, the hardness of samples BA- 6 
and BA-8 were measured, and the load was designed to be $50 \mathrm{gf}$ with a dwelling time of $10 \mathrm{~s}$. It is interesting to observe that an extremely hard surface layer with Vickers hardness values over $1500 \mathrm{HV}$ is synthesized on the treated samples by the boro-austempering processing route. The hardness of the compound layers is about 3.5-fold of the bainitic substrate. Türkmen et al. [30] reported that the hardness of borided layers was in the range of 1200 2000 HV. Toktaş et al. [31] obtained the hardness of 1300 1700 HV of borided layers. Mariani et al. [21] demonstrated that the microhardness of borided layers on ductile cast irons was 1400 1700 HV. Similar results were also revealed by Oliveira et al. [18]. In this study, the attained hardness of borided layers on bainitic steels was consistent with those found in the above-mentioned literature.

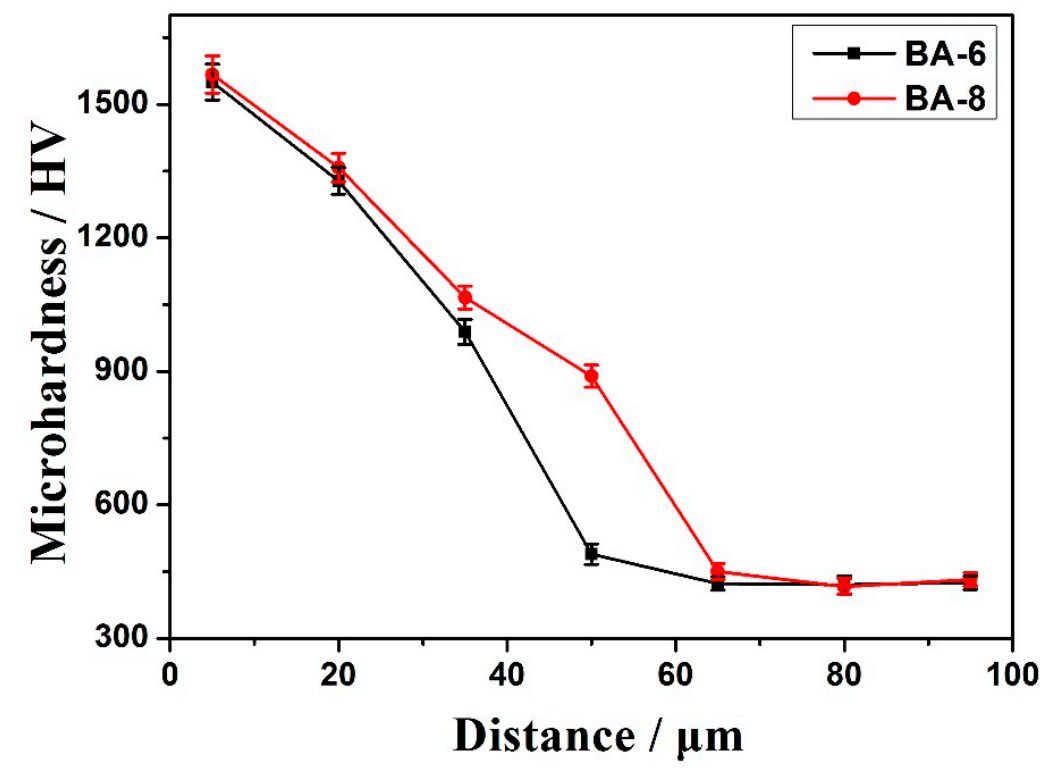

Figure 9. Hardness profiles from the outermost produced layer to the substrate.

\subsection{Corrosion Behavior}

Polarization curves at the stabilized open circuit potential were used to detect the corrosion kinetics of samples in $10 \% \mathrm{NaOH}, 0.5 \mathrm{~mol} / \mathrm{L} \mathrm{HCl}$ and $3.5 \% \mathrm{NaCl}$ solutions for simulating alkaline, acidic and neutral environments, respectively. Figure 10 exhibits the potentiodynamic polarization curves of boro-austempered sample BA-2 and its comparable sample NA-2, respectively. The related values of free corrosion current density $\left(I_{\text {corr }}\right)$ and free corrosion potential ( $E_{\text {corr }}$ ) of samples BA-2 and NA-2 in different corrosive mediums can be extracted from polarization curves, as listed in Table 3 . The values of $E_{\text {corr }}$ in different corrosive mediums of sample BA-2 are larger, and the $I_{\text {corr }}$ data are smaller compared to those of sample NA-2, testifying that the boro-austempered sample yields better corrosive performance in alkaline, acidic, and neutral environments. The improved corrosion resistance by boro-austempering treatments is mainly ascribed to the formation of $\mathrm{FeB}$ and $\mathrm{Fe}_{2} \mathrm{~B}$. It was well accepted that a dense and uniform borided layer formed during the boriding process. This is conducive to suppressing the entry of corrosive medium. On the other hand, the bonding force between $\mathrm{FeB}$ and $\mathrm{Fe}_{2} \mathrm{~B}$ phases is much greater than the matrix's, which is beneficial to resisting the corrosive damage. In addition, it can be observed that the anodic curves of samples in $10 \% \mathrm{NaOH}$ fluctuate, which is related to the activation-passivation transition on the surface of the sample [32]. 

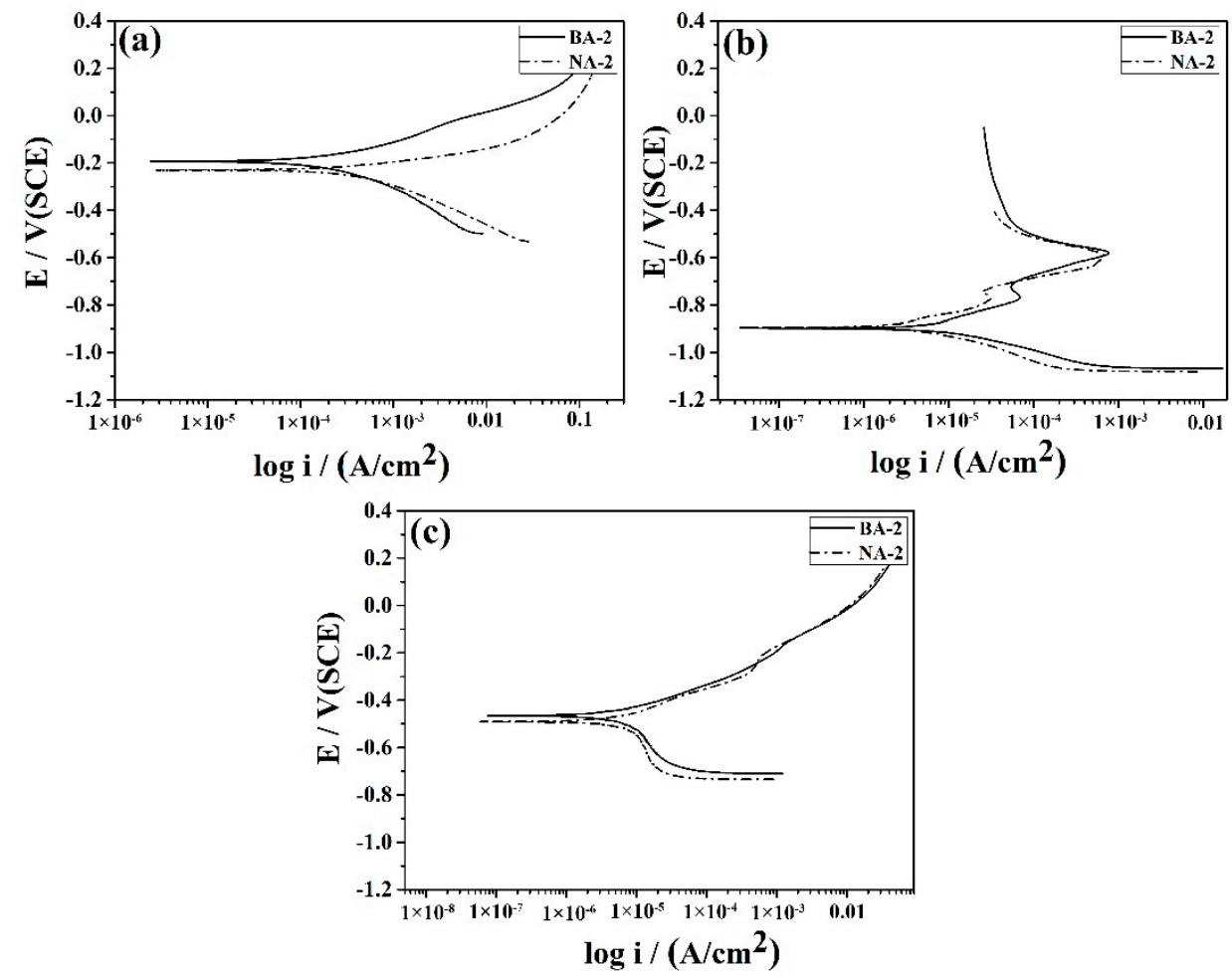

Figure 10. Effect of the boriding process (BA-2) on the potentiodynamic polarization curves in different corrosive mediums: (a) $0.5 \mathrm{~mol} / \mathrm{L} \mathrm{HCl}$; (b) $10 \% \mathrm{NaOH}$; (c) $3.5 \% \mathrm{NaCl}$.

Table 3. The $I_{\text {corr }}$ and $E_{\text {corr }}$ of samples BA-2 and NA-2 in different corrosive mediums.

\begin{tabular}{ccccccc}
\hline \multirow{2}{*}{ Samples } & \multicolumn{2}{c}{$\mathbf{1 0} \% \mathbf{~ N a O H}$} & \multicolumn{2}{c}{$\mathbf{0 . 5} \mathbf{~ m o l} / \mathbf{L ~ H C l}$} & \multicolumn{2}{c}{$3.5 \% \mathrm{NaCl}$} \\
& $I_{\text {corr }}\left(\mathrm{A} / \mathbf{c m}^{2}\right)$ & $E_{\text {corr }}(\mathrm{V})$ & $I_{\text {corr }}\left(\mathbf{A} / \mathbf{c m}^{2}\right)$ & $E_{\text {corr }}(\mathrm{V})$ & $I_{\text {corr }}\left(\mathrm{A} / \mathbf{c m}^{2}\right)$ & $E_{\text {corr }}(\mathrm{V})$ \\
\hline BA-2 & $2.54 \times 10^{-6}$ & -0.895 & $5.50 \times 10^{-5}$ & -0.193 & $2.13 \times 10^{-6}$ & -0.466 \\
NA-2 & $3.93 \times 10^{-6}$ & -0.899 & $1.49 \times 10^{-4}$ & -0.230 & $3.04 \times 10^{-6}$ & -0.491 \\
\hline
\end{tabular}

Because of the excellent corrosion behaviors of boro-austempered samples [19], the surface of the boro-austempered sample (BA-2) in the present study was artificially scratched by an electric marker to expose the matrix, working as an active anode around the harder produced layer before in situ SVET tests. According to the corrosive medium used during SVET tests in the literature $[23,33]$, the $0.5 \% \mathrm{NaCl}$ solution was also chosen in the present study. Figure 11 gives the current density maps of the BA-2 sample at various immersion times in $0.5 \% \mathrm{NaCl}$ solution. It is directly observed that anodic activity is detected at the beginning of immersion (Figure 11a). In addition, the scratched area exhibits a relatively higher current density as compared to circumambient as-prepared layers during the immersed period. Moreover, the anodic current density successively increases from $47.8 \mathrm{~mA} / \mathrm{cm}^{2}$ after $0.5 \mathrm{~h}$ exposure, and finally to $139 \mathrm{~mA} / \mathrm{cm}^{2}$ after $3.5 \mathrm{~h}$ exposure, while the corroded area gradually contracts during immersion in $0.5 \% \mathrm{NaCl}$ solution. Therefore, the corrosion reaction is supposed to proceed predominantly along the depth direction instead of horizontal propagation. The above phenomenon demonstrates the excellent corrosion performance of the fabricated layers on bainitic steels. 

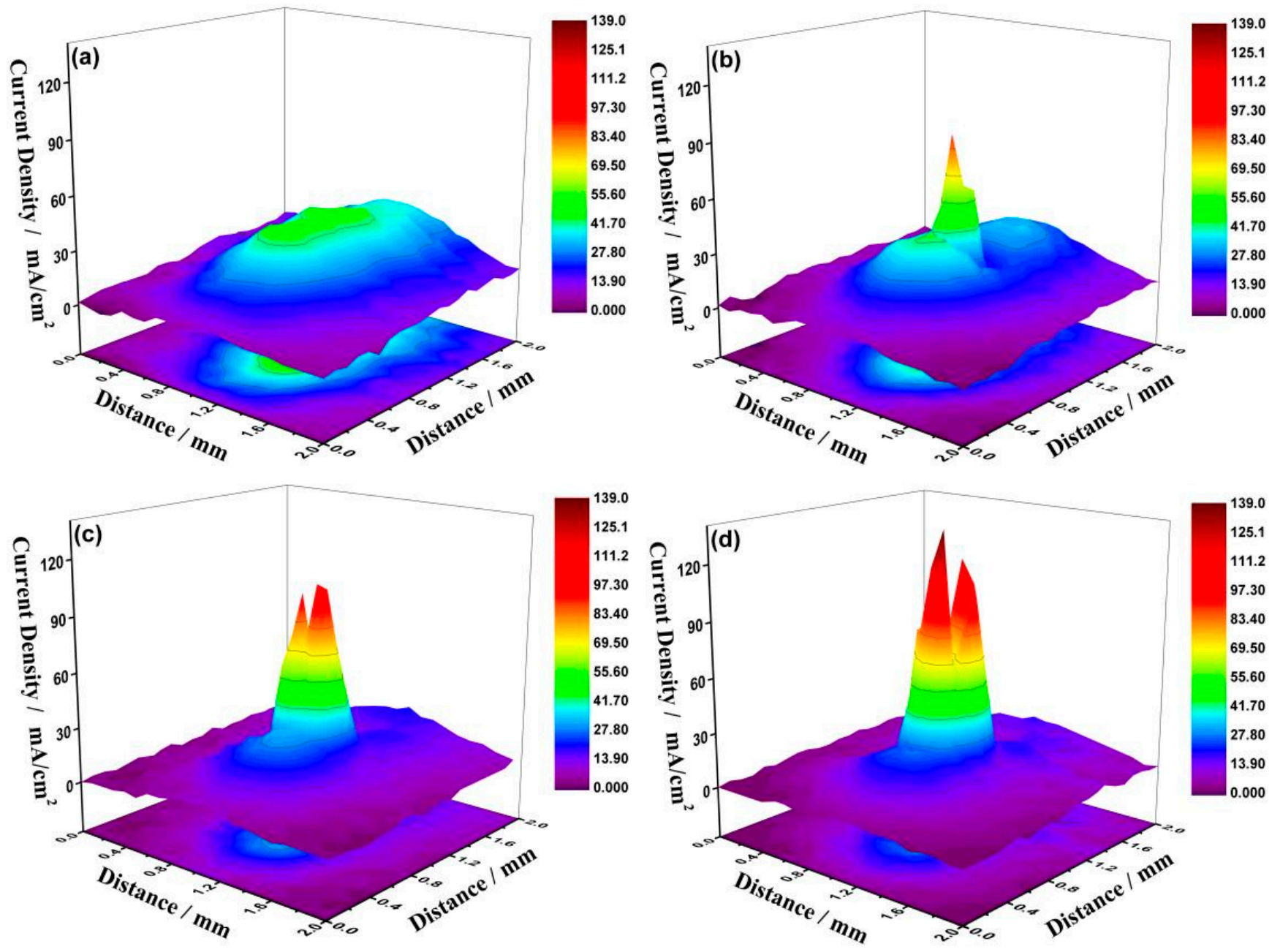

Figure 11. Effect of the immersion time on in situ SVET images of boro-austempered steel in $0.5 \% \mathrm{NaCl}$ solution: (a) $0.5 \mathrm{~h}$; (b) $1.5 \mathrm{~h}$; (c) $2.5 \mathrm{~h}$; (d) $3.5 \mathrm{~h}$.

\subsection{Wear Behaviors}

Friction tests of different samples were conducted on a BMT-I multifunctional surface performance comprehensive tester. The friction coefficients of samples were continuously recorded during the whole process, as presented in Figure 12. It can be observed that the average friction coefficient of the untreated sample (NA-2) is about 0.75, while the average friction coefficients of the boro-austempered samples (BA-2 and BA-8) are around 0.60. Carrera-Espinoza et al. [34] and Almeida et al. [35] reported that the friction coefficients of produced layers by only boriding were smaller than the samples without boriding. Hence, the changing trend of the friction coefficient of as-prepared layers after the boro-austempering process is similar to that in boriding only. Generally, the wear rate is positively correlated with the friction coefficient, which means the larger the friction coefficient, the larger the wear rate. Hence, the larger friction coefficient of sample NA-2 resulted in larger wear loss under the same wear condition. Therefore, the wear performance of bainitic steels is significantly enhanced by boro-austempering treatment. 


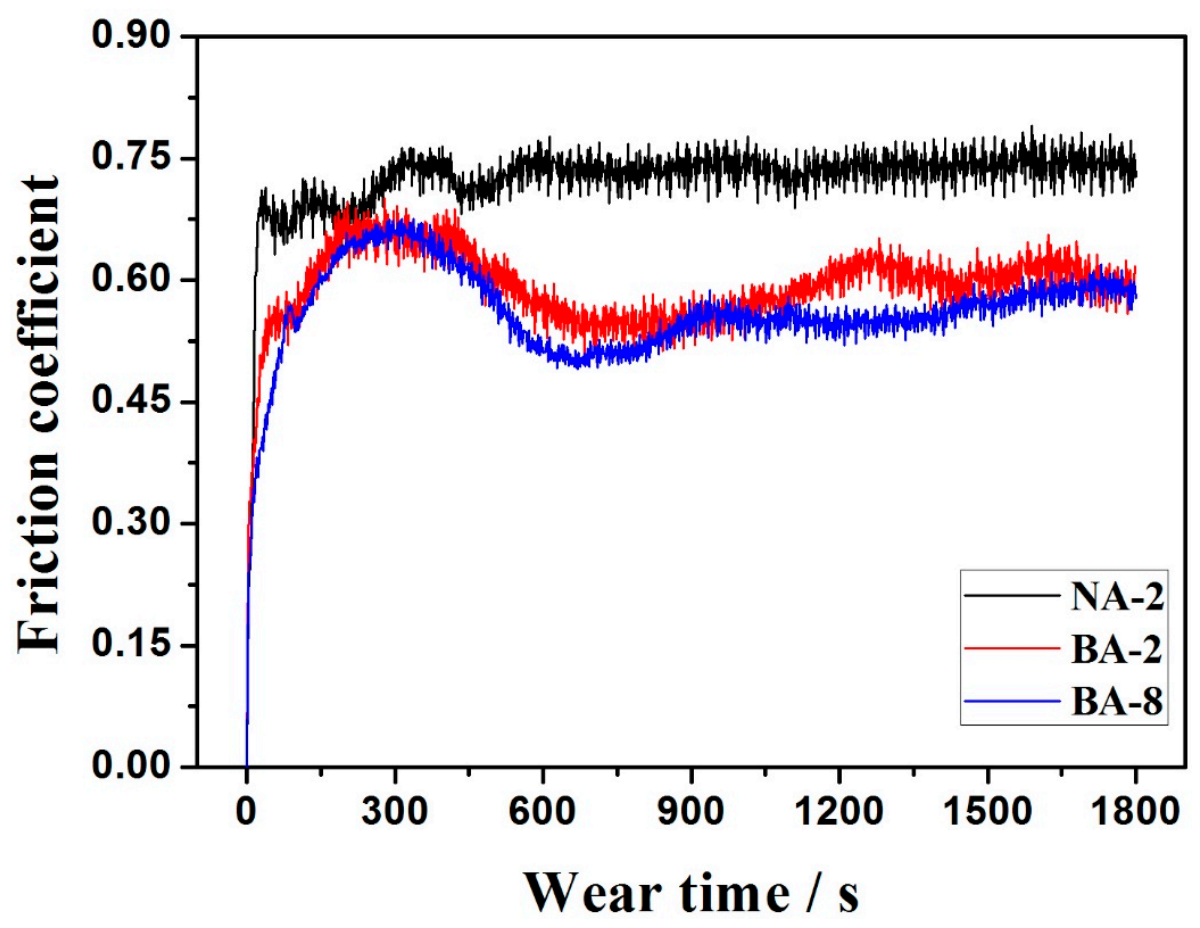

Figure 12. Friction coefficients recorded under dry sliding for different samples.

Figure 13 displays the morphologies of wear tracks in samples BA-2 and NA-2. It is observed that there are abrasion grooves along the sliding direction in both BA-2 and NA-2, and both samples exhibit the integrity of wear track regardless of different friction coefficients. In addition, there are some peeling areas in the boro-austempered sample (BA2), as shown in Figure 13c,d. This may be attributed to a different wear mechanism from pure abrasion of the sample without boriding (NA-2). Gutierrez-Noda et al. [36] claimed that it was the delamination wear mechanism for borided samples. It is reasonable to speculate that the delamination wear mechanism is also applicative for boro-austempered samples. Moreover, the wear track depth and width in both samples were measured by an ultra-depth, three-dimensional microscope. The average wear track width and depth of the non-borided sample are $718 \pm 15$ and $12.43 \pm 3.23 \mu \mathrm{m}$, respectively, while the average wear track width and depth of the boro-austempered sample are $408 \pm 7$ and $2.88 \pm 1.07 \mu \mathrm{m}$, respectively. It should be emphasized that the wear track of the untreated sample is approximately 1.7 times wider and 4.3 times deeper than the boro-austempered sample. Since the subsequent isothermal holding at $623 \mathrm{~K}$ for one hour for bainitic precipitation acts equivalently as the tempering process of borided layers, the brittleness of the produced layer is significantly reduced. Meanwhile, the intrinsic higher-hardness of the borided layer further improves the wear resistance, and consequently, the shallow and narrow wear tracks occupy the surface of boro-austempered steels. 

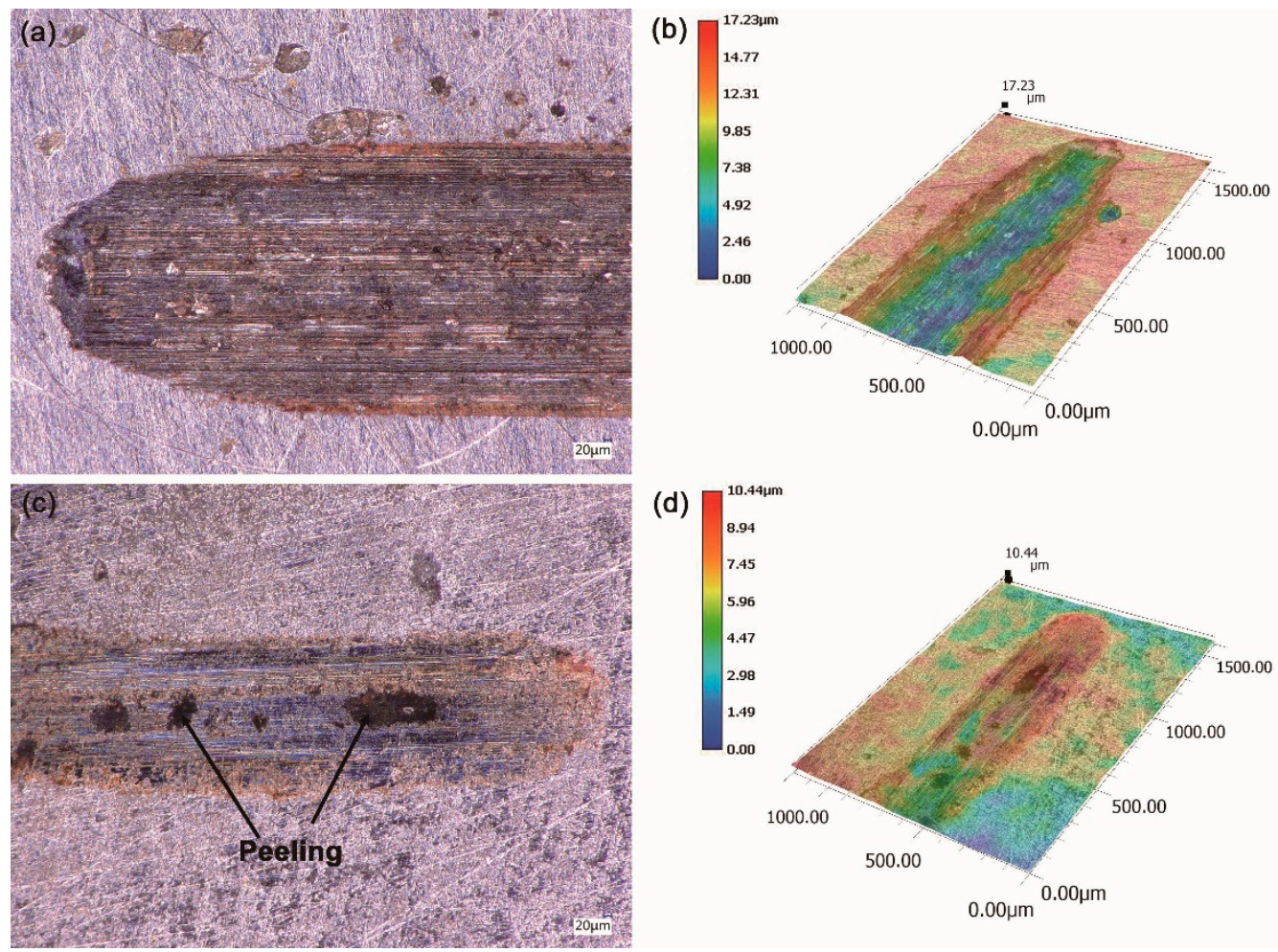

Figure 13. Morphologies of wear tracks of samples: (a) and (b) NA-2; (c) and (d) BA-2.

Wear tests were conducted on an ML-100 wear resistance machine. Figures 14 and 15 present the wear loss of samples BA-2 and NA-2 at different wear durations and the wear morphologies of the samples, respectively. The wear loss of the comparable sample NA-2 $(450 \mathrm{mg})$ is 2.2 times the boro-austempered sample BA-2 $(204 \mathrm{mg})$, demonstrating that the as-prepared layer on the surface significantly improves the wear resistance of the bainitic steel. In addition, for the boro-austempered sample (BA-2) in Figure 14b, the wear rate (the slope of the wear loss curve) increases after a $720 \mathrm{~m}$ sliding distance, meaning that the as-prepared layer begins to desquamate. This may be related to the thinner layers $(28.6 \mu \mathrm{m})$ of sample BA-2. Regarding the wear morphologies of samples in Figure 15, the parallel scratches denoting two-body wear are observed in two samples. However, it is apparent that the parallel scratches in sample NA-2 are more intense and deeper than those of the boro-austempered sample (BA-2), which is consistent with the results of wear loss.
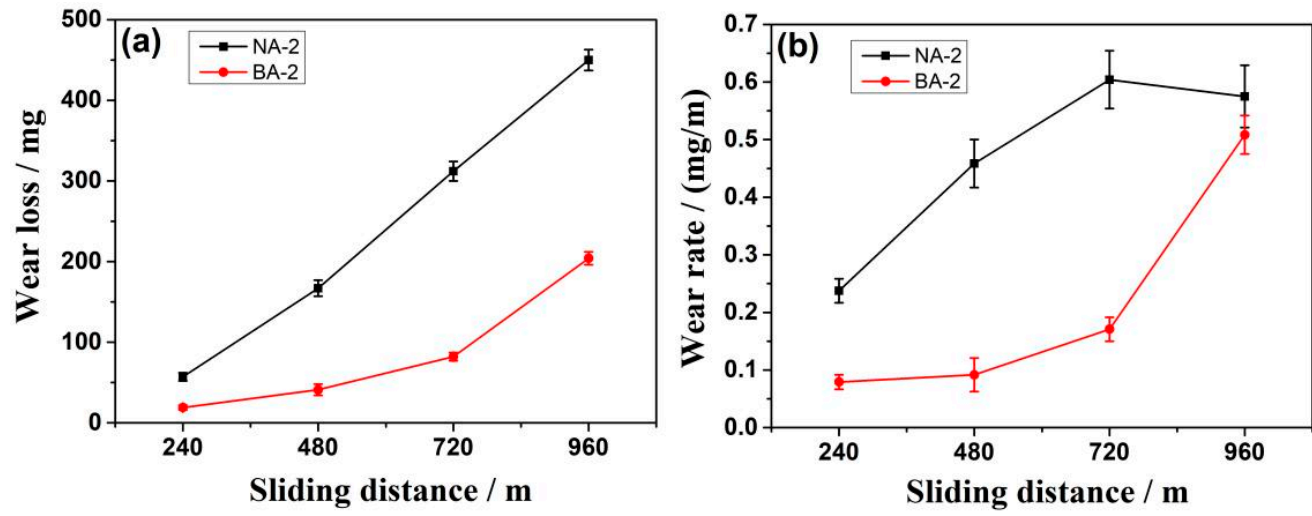

Figure 14. (a) wear loss and (b) wear rate of samples BA-2 and NA-2 in different wear durations. 

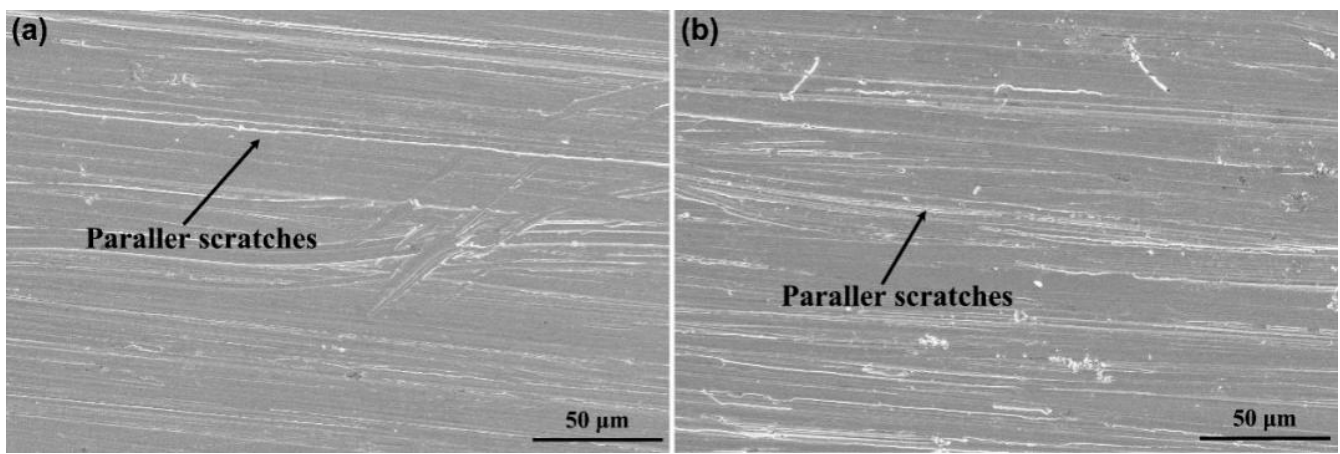

Figure 15. SEM wear morphologies of samples (a) BA-2 and (b) NA-2 after sliding abrasion.

\section{Conclusions}

The effects of boro-austempering treatments on growth kinetics in borided layers, microstructure, and properties in medium-carbon bainitic steel were investigated. The main conclusions obtained are as follows. The corrosion resistance of steels in $10 \% \mathrm{NaOH}$ solution, $0.5 \mathrm{~mol} / \mathrm{L} \mathrm{HCl}$ solution, and $3.5 \% \mathrm{NaCl}$ were apparently improved via boroaustempering treatment. In addition, the surface friction coefficient reduced by $20 \%$ after boro-austempering, and the wear resistance of the as-prepared layer improved up to 2.2 times compared to the bainitic substrates. The produced layer on the bainite matrix exhibited superior adhesion strength. Moreover, the boundaries between the bcc structure and $\mathrm{Fe}_{2} \mathrm{~B}$ grains as well as between $\mathrm{Fe}_{2} \mathrm{~B}$ and $\mathrm{FeB}$ grains were low-angle boundaries. The preferential crystallographic growth directions of $\mathrm{Fe}_{2} \mathrm{~B}$ and $\mathrm{FeB}$ are [001] and [010], respectively, which belongs to the (100) plane. Furthermore, there were large amounts of boron content in the coating and fewer carbon atoms, and the boride contained no $\mathrm{Si}$ element. Si hindered the growth of borided layers, and $\mathrm{C}$ impeded the diffusion of $\mathrm{B}$ atoms. Finally, the thickness of compound layers ranged from 3.4 to $62.9 \mu \mathrm{m}$ in the boriding time, and the kinetics equation $\mathrm{d}^{2}=0.125 \cdot \mathrm{t}$ for the as-prepared layers on the tested steel at $1223 \mathrm{~K}$ was obtained.

Author Contributions: M.L. doctoral student, conducted experiments, analyzed the data and wrote the paper; W.W. chief researcher, designed experiments and analyzed the data; H.H. associate professor, conducted experiments and analyzed the data; F.C. master student, conducted experiments and analyzed the data; S.L. lecturer, conducted experiments and analyzed the data; G.X. supervisor, conceived and designed the experiments. All authors have read and agreed to the published version of the manuscript.

Funding: The National Natural Science Foundation of China (NSFC) (51874216) and the Key Project of Hebei Iron and Steel Group (HG219313).

Institutional Review Board Statement: Not applicable.

Informed Consent Statement: Not applicable.

Data Availability Statement: The data that supports the findings of this study are available within the paper.

Conflicts of Interest: The authors declare no conflict of interest. The founding sponsors had no role in the design of the study; in the collection, analyses, or interpretation of data; in the writing of the manuscript, or in the decision to publish the results.

\section{References}

1. Garcia-Mateo, C.; Caballero, F.G.; Bhadeshia, H.K.D.H. Development of hard bainite. ISIJ Int. 2003, 43, 1238-1243. [CrossRef]

2. Bhadeshia, H.K.D.H. Nanostructured bainite. Proc. R. Soc. A 2010, 466, 3-18. [CrossRef]

3. Garcia-Mateo, C.; Caballero, F.G.; Bhadeshia, H.K.D.H. Mechanical properties of low-temperature bainite. Mater. Sci. Forum. 2005, 500, 495-502. [CrossRef] 
4. Caballero, F.G.; Bhadeshia, H.K.D.H.; Mawella, K.J.A.; Jones, D.G.; Brown, P. Very strong low temperature bainite. Mater. Sci. Technol. 2002, 18, 279-284. [CrossRef]

5. Wang, Y.H.; Zhang, F.C.; Wang, T.S. A novel bainitic steel comparable to maraging steel in mechanical properties. Scr. Mater. 2013, 68, 763-766. [CrossRef]

6. Tian, J.Y.; Xu, G.; Jiang, Z.Y.; Hu, H.J.; Zhou, M.X. Effect of Ni addition on bainite transformation and properties in a $2000 \mathrm{MPa}$ grade ultrahigh strength bainitic steel. Met. Mater. Int. 2018, 24, 1202-1212. [CrossRef]

7. Chen, G.H.; Hu, H.J.; Xu, G.; Tian, J.Y.; Wan, X.L.; Wang, X. Optimizing microstructure and property by ausforming in a medium-carbon bainitic steel. ISIJ Int. 2020, 60, 2007-2014. [CrossRef]

8. Tian, J.Y.; Xu, G.; Hu, H.J.; Wang, X.; Zurob, H.S. Transformation kinetics of carbide-free bainitic steels during isothermal holding above and below MS. J. Mater. Res. Technol. 2020, 9, 13594-13606. [CrossRef]

9. Gao, G.H.; Guo, H.R.; Gui, X.L.; Tan, Z.L.; Bai, B.Z. Inverted multi-step bainitic austempering process routes: Enhanced strength and ductility. Mater. Sci. Eng. A 2018, 736, 298-305. [CrossRef]

10. Wang, Z.H.; Hui, W.J.; Chen, Z.; Zhang, Y.J.; Zhao, X.L. Effect of vanadium on microstructure and mechanical properties of bainitic forging steel. Mater. Sci. Eng. A 2020, 771, 138653. [CrossRef]

11. Senthil, P.P.; Rao, K.S.; Nandi, H.K.; Singh, V.; Kumar, S.; Sankaran, S.; Kumar, K.S.; Madhu, V. Influence of niobium microalloying on the microstructure and mechanical properties of high carbon nano bainitic steel. Procedia Struct. Integr. 2019, 14, 729-737. [CrossRef]

12. Kirbiš, P.; Anžel, I.; Rudolf, R.; BrunÄko, M. Novel approach of nanostructured bainitic steels' production with improved toughness and strength. Materials 2020, 13, 1220. [CrossRef]

13. Kumar, A.; Singh, A. Toughness dependence of nano-bainite on phase fraction and morphology. Mater. Sci. Eng. A 2018, 729, 439-443. [CrossRef]

14. Golchin, S.; Avishan, B.; Yazdani, S. Effect of $10 \%$ ausforming on impact toughness of nano bainite austempered at $300{ }^{\circ} \mathrm{C}$. Mater. Sci. Eng. A 2016, 656, 94-101. [CrossRef]

15. Edwards, R.H.; Kennon, N.F. The morphology and mechanical properties of bainite formed from deformed austenite. Metall. Mater. Trans. A 1978, 9, 801-1809. [CrossRef]

16. Fabijanic, D.; Timokhina, I.; Beladi, H.; Hodgson, P. The nitrocarburising response of low temperature bainite steel. Metals 2017, 7, 234. [CrossRef]

17. Natori, M.; Mizuno, Y.; Song, S.M.; Sugimoto, K.I. Effects of fine particle peening on fatigue strength of TRIP-aided bainitic ferrite steel. J. Soc. Mater. Sci. Jpn. 2015, 64, 620-627. [CrossRef]

18. Oliveira, P.G.B.D.; Mariani, F.E.; Casteletti, L.C.; Filho, A.I.; Neto, A.L.; Totten, G.E. Boro-austempering treatment of high-strength bainitic steels. J. Mater. Eng. Perform. 2020, 17, 3486-3493. [CrossRef]

19. Liu, M.; Wang, Z.T.; Pan, C.G.; Zhang, Q.; Hu, H.J.; Xu, G. Microstructure and properties of a medium-carbon high-strength bainitic steel treated by boro-austempering treatment. Steel Res. Int. 2020, 91, 2000128. [CrossRef]

20. Mariani, F.E.; Bortoluci de Assis, G.; Casteletti, L. Austempering and boro-austempering treatments in gray cast iron. Mater. Perform. Charact. 2017, 6, 262-271. [CrossRef]

21. Mariani, F.E.; Soares, C.; Neto, A.L. Boro-austempering treatment of ductile cast irons. Mater. Res. 2018, 21, e20170927. [CrossRef]

22. Moreto, J.A.; Marino, C.E.B.; Filho, W.W.B.; Rocha, L.A.; Fernandes, J.C.S. SVET, SKP and EIS study of the corrosion behaviour of high strength $\mathrm{Al}$ and Al-Li alloys used in aircraft fabrication. Corros. Sci. 2014, 84, 30-41. [CrossRef]

23. Zhang, X.; Wei, W.Z.; Cheng, L.; Liu, J.; Wu, K.M.; Liu, M. Effects of niobium and rare earth elements on microstructure and initial marine corrosion behavior of low-alloy steels. Appl. Surf. Sci. 2019, 475, 83-93. [CrossRef]

24. Tian, J.Y.; Xu, G.; Jiang, Z.Y.; Yuan, Q.; Chen, G.H.; Hu, H.J. Effect of austenisation temperature on bainite transformation below martensite starting temperature. Mater. Sci. Technol. 2019, 35, 1539-1550. [CrossRef]

25. Chen, F.S.; Wang, K.L. The kinetics and mechanism of multi-component diffusion on AISI 1045 steel. Surf. Coat. Technol. 1999, 115, 239-248. [CrossRef]

26. Zhong, J.R.; Qin, W.; Wang, X.; Medvedovski, E.; Szpunar, J.A.; Guan, K.S. Mechanism of texture formation in iron boride coatings on low-carbon steel. Metall. Mater. Trans. A 2019, 50, 58-62. [CrossRef]

27. Verein Deutscher Ingenieure Normen; VDI 3198; VDI-Verlag: Dusseldorf, Germany, 1991.

28. Sireli, G.K.; Bora, A.S.; Timur, S. Evaluating the mechanical behavior of electrochemically borided low-carbon steel. Surf. Coat. Technol. 2020, 381, 125177. [CrossRef]

29. Vidakis, N.; Antoniadis, A.; Bilalis, N. The VDI 3198 indentation test evaluation of a reliable qualitative control for layered compounds. J. Mater. Process. Technol. 2003, 143, 481-485. [CrossRef]

30. Türkmen, İ.; Yalamaç, E.; Keddam, M. Investigation of tribological behaviour and diffusion model of Fe2B layer formed by pack-boriding on SAE 1020 steel. Surf. Coat. Technol. 2019, 377, 124888. [CrossRef]

31. Tokta, A.; Tokta, G.; Gülsün, K. Effect of boronizing parameters and matrix structures on the wear property of ductile iron. Int. Sci. J. Mach. Technol. Mater. 2018, 12, 33-36.

32. Zhang, H.W.; Man, C.; Wang, L.W.; Dong, N.C.F.; Wang, L.; Kong, D.C.; Wang, X. Different corrosion behaviors between $\alpha$ and $\beta$ phases of Ti6Al4V in fluoride-containing solutions: Influence of alloying element Al. Corros. Sci. 2020, 169, 108605. [CrossRef]

33. Wei, W.Z.; Wu, K.M.; Zhang, X.; Liu, J.; Qiu, P.; Cheng, L. In-situ characterization of initial marine corrosion induced by rare-earth elements modified inclusions in Zr-Ti deoxidized low-alloy steels. J. Mater. Res. Technol. 2020, 9, 1412-1424. [CrossRef] 
34. Carrera-Espinoza, R.; Figueroa-López, U.; Martínez-Trinidad, J.; Campos-Silva, I.; Hernández-Sánchez, E.; Motallebzadeh, A. Tribological behavior of borided AISI 1018 steel under linear reciprocating sliding conditions. Wear 2016, 362, 1-7. [CrossRef]

35. Dos, S.; de Almeida, E.A.; Milan, J.C.G.; Costa, H.L.; Krelling, A.P.; da Costa, C.E. Sliding wear of borided sintered AISI M2 steel coated with AlTiN/CrN multilayer. Wear 2018, 410, 11-24.

36. Gutierrez-Noda, L.; Cuao-Moreu, C.A.; Perez-Acosta, O.; Lorenzo-Bonet, E.; Zambrano-Robledo, P.; Hernandez-Rodriguez, M.A.L. The effect of a boride diffusion layer on the tribological properties of AISI M2 steel. Wear 2019, 426, 1667-1671. [CrossRef] 